\title{
ВЕСЕННИЙ ПОВЕРХНОСТНЫЙ СКЛОНОВЫЙ СТОК НА РУССКОЙ РАВНИНЕ В ГОДЫ РАЗЛИЧНОЙ ВОДНОСТИ
}

\author{
(C) 2020 г. Е. А. Кашутина ${ }^{a}$, С. В. Ясинский ${ }^{a}$, Н. И. Коронкевич ${ }^{a}$, * \\ ${ }^{a}$ Институт географии Российской академии наук, Москва, Россия \\ *e-mail: hydro-igras@yandex.ru \\ Поступила в редакцию 13.05.2019 г. \\ После доработки 02.07.2019 г. \\ Принята к публикации 03.10.2019 г.
}

\begin{abstract}
Показана важная гидрологическая и гидроэкологическая роль поверхностного склонового стока, особенно весеннего (ВПСС) в функционировании геосистем. Выполнено обобщение данных 28 воднобалансовых станций о его величине на территории Русской равнины в годы разной водности. Оценена гидрологическая роль зяблевой пахоты в лесостепной и степной зонах, которая выражается в уменьшении ВПСС на зяби по сравнению с полями, не распахиваемыми осенью, причем наиболее ощутимо в многоводные и средние по водности годы. Исключение составляют самые маловодные годы, когда поверхностный склоновый сток на всех угодьях отсутствует. Рассмотрены два периода - с 1920-х годов по 1980 г. и с 1981 по настоящее время, различающиеся характеристиками климата и антропогенного воздействия. Установлено, что ВПСС во второй период резко (в несколько раз) снизился, главным образом в результате изменения климата, что имеет как позитивные, так и негативные последствия.
\end{abstract}

Ключевые слова: весеннее снеготаяние, поверхностный склоновый сток, зяблевая пахота, не распахиваемые осенью поля, периоды до 1980 и после 1981 г., изменения, последствия

DOI: $10.31857 / \mathrm{S} 2587556620010100$

\section{ВВЕДЕНИЕ}

Наиболее ярким и важным периодом в годовом цикле функционирования наземных и водных геосистем на Русской равнине является весеннее снеготаяние. Главным образом в этот период, а также во время выпадения сильных дождей по склонам водосборов рек и других водных объектов (озер, водохранилищ, болот и др.) текут потоки воды, насыщенные взвешенными твердыми и растворенными в воде химическими вешествами. Явление движения талых и/или дождевых вод по наклонным поверхностям различных естественных и природно-антропогенных геосистем (лесов, сельскохозяйственных угодий, горных отвалов, строительных и промышленных площадок, урбанизированных территорий и др.) называется поверхностным (талым или дождевым) склоновым стоком (ПСС, в весенний период ВПСС).

При этом имеется в виду, что под склонами понимается та часть водосбора, которая в общем случае располагается выше бровок оврагов, балок, речных долин и других элементов гидрографической сети. Именно на склонах, включая и плакорные участки, располагается основная часть сельскохозяйственных полей и других природно-антропогенных геосистем.

В реальных условиях собственно поверхностный сток наблюдается довольно редко. Обычно поверхностный сток включает определенное количество воды, находящееся в почвах и грунтах. Чем длиннее путь стекающей воды, тем вероятнее участие в нем “подповерхностного”, “подпокровного”, "почвенного", "почвенно-грунтового", “стока верховодки" и даже подземного стока [26, 28]. Кроме того, практически никогда на склонах вода не стекает сплошным слоем, а течет в микроруслах, сформированных водными потоками эфемерной микроручейковой и ручейковой сети. В зависимости от морфологии элементарных склонов сельскохозяйственных водосборов (прямые, выпуклые, вогнутые, выпукло-вогнутые, волнистые), линии стока могут образовывать различный пространственный рисунок этой сети, характеристика которых приведена в [7, 28].

В формировании и функционировании различных геосистем ПСС выполняет две важные взаимообусловленные функции. Во-первых, он в значительной мере обусловливает величину ежегодного общего притока воды в реки, озера и водохранилища [1]. Во-вторых, ПСС - основной 
фактор формирования таких негативных явлений, как эрозия почвы и оврагообразование, а также диффузного (рассеянного) загрязнения водных объектов, в том числе биогенными элементами, во многом определяющими их антропогенное эвтрофирование [2, 16, 21, 30]. По современным оценкам, площадь эрозионно-опасных и подверженных водной и ветровой эрозии сельскохозяйственных земель в России составляет 124.7 млн га (или 40\%), в том числе эродированных - 54.1 млн га (21.2\%) [27]. Общий среднегодовой вынос с пашни только валовых форм биогенных элементов - азота, фосфора, калия с эрозией почвы в реки и водоемы оценивается в целом для России в 14350 тыс. т, а фосфора и азота - 2546 тыс. т [28]. Биогенные вещества выносятся в водные объекты с ПСС как во взвешенном (продукты эрозии), так и в растворенном виде. В результате почвами только центра и юга Русской равнины теряется в год от 435 до 900 тыс. биогенных элементов, а в результате только эрозионных процессов в этом регионе от 1500 до 2000 тыс. т органического вещества [36]. Потоки этих веществ, а также ядохимикатов и радионуклидов, выносимые ПСС с водосборов, трансформируются гидрографической сетью и, поступая в водные объекты, приводят не только к их усиленному эвтрофированию, но и совместно со сточными водами от точечных источников обусловливают общее загрязнение водных объектов. Имеющиеся в литературе данные свидетельствуют о том, что вклад этого вида загрязнения в формирование качества воды может быть весьма существенным. В некоторых случаях вынос органических веществ и других загрязняющих веществ с водосборов может превосходить по абсолютной величине их поступление от точечных источников и достигать от 50 до $80 \%$ общего их притока в водные объекты [11, 12, 31, 34, 37].

Основной фактор формирования ПСС и ВПСС - климатический. В условиях центральной и восточной части равнинной России особое значение приобретают снегозапасы и условия снеготаяния. Как показано в [33], дождевые осадки, если они не выпадают в период весеннего половодья, крайне редко формируют поверхностный склоновый сток. Дождевой поверхностный сток в теплое время года имеет место в этих районах в основном на площади гидрографической сети. Средние многолетние снегозапасы и осадки за период снеготаяния на открытых, безлесных склонах в этих районах составляют 140-170 мм в южной части лесной зоны, 100-120 мм - в лесостепи, 70-90 мм - в степных районах. В лесу соответствующие значения составляют: 170-190, 140160, 110-130 мм. В овражно-балочной сети, куда с ветром сносится с полей снег, эти величины могут быть в 2-3 раза больше, чем в поле [23]. Колебаниями метеорологических условий в первую очередь объясняются многократные (по сравне- нию со средним многолетним стоком) изменения поверхностного стока в многоводные и маловодные годы.

В степной зоне склонового стока в маловодные годы практически не наблюдается. Вместе с тем в условиях высоких снегозапасов, сформировавшихся на хорошо увлажненных с осени и промерзших почвах, наблюдаются экстремально высокие его значения. В этой зоне несколько многоводных лет практически определяют среднее многолетнее значение стока половодья и интенсивности эрозии почвы.

Изучению весеннего поверхностного склонового стока на территории Русской равнины на основании данных воднобалансовых (стоковых) станций посвящено немало работ [1, 3, 5, 6, 14, 17, $22,26,29,39]$. Но большая часть этих работ выполнена уже довольно давно, характеризует в основном средние многолетние значения стока и не отражает в полной мере произошедшие в последние годы климатические изменения и изменения в структуре сельскохозяйственных угодий. В данной статье предпринята попытка учесть эти изменения применительно к ВПСС в годы различной водности.

\section{ИСХОДНЫЕ МАТЕРИАЛЫ И МЕТОДЫ ОЦЕНКИ ВЕСЕННЕГО ПОВЕРХНОСТНОГО СКЛОНОВОГО СТОКА}

Основу в расчетах ВПСС составляют данные воднобалансовых станций, представляющие собой результаты наблюдений за ВПСС на стоковых площадках. Перечень воднобалансовых станций, данные которых использованы в статье, а также о средних, максимальных и минимальных значениях стока, полученных на каждой воднобалансовой станции за годы наблюдений, представлены в табл. 1. В гидрологии сформулированы следующие критерии оценки водности года по речному стоку: многоводные - до $25 \%$ вероятности превышения, оцениваемой по многолетнему ряду стока, средние по водности годы - от 25 до $75 \%$, маловодные - от 75\% и больше [15, 24, 25]. Применим эти критерии и для склонового стока.

Обобщение данных экспериментальных наблюдений за склоновым стоком сопряжено со значительными трудностями. Прежде всего, они связаны с короткими временными рядами наблюдений за склоновым стоком, не превышающими 15-30 лет на большинстве весьма редкой сети воднобалансовых станций Роскомгидромета, а также стационаров другой ведомственной принадлежности. И лишь на некоторых из них наблюдения ведутся около 40-50 лет [4, 19, 38]. Причем они охватывают периоды, существенно отличающиеся по климатическим условиям. Кроме того, весьма различны как число объектов, 
Таблица 1. Весенний поверхностный склоновый сток по данным воднобалансовых станций

\begin{tabular}{|c|c|c|c|c|c|c|}
\hline \multirow[b]{2}{*}{ Зона } & \multirow[b]{2}{*}{ Станция } & \multirow[b]{2}{*}{ Годы наблюдений } & \multirow{2}{*}{$\begin{array}{c}\text { Состояние сельско- } \\
\text { хозяйственных } \\
\text { угодий осенью }\end{array}$} & \multicolumn{3}{|c|}{ Сток, мм } \\
\hline & & & & \begin{tabular}{|c|} 
мини- \\
мальный
\end{tabular} & $\begin{array}{c}\text { макси- } \\
\text { мальный }\end{array}$ & $\begin{array}{l}\text { сред- } \\
\text { ний }\end{array}$ \\
\hline Лесная & $\begin{array}{l}\text { Барыбинский стационар } \\
\text { ВИУА }\end{array}$ & $1952-1954$ & Зябь, н/п* & 23.0 & 165.0 & 75.0 \\
\hline Лесная & $\begin{array}{l}\text { Валдайская воднобалансо- } \\
\text { вая станция }\end{array}$ & $1965-1977$ & Зябь, н/п & 3.4 & 115.4 & 49.3 \\
\hline Лесная & \begin{tabular}{|l} 
Вилайняй - воднобалансо- \\
вая станция
\end{tabular} & $\begin{array}{c}1972-1975,1977-1980,1983 \\
1985\end{array}$ & Зябь, н/п & 0.0 & 115.7 & 23.0 \\
\hline Лесная & Вологда (Семенково) & 1975-1978, 1980, 1983, 1985 & Зябь, н/п & 46.9 & 162.2 & 85.4 \\
\hline Лесная & Загорский стационар ИГ АН & $1958-1961$ & Зябь, н/п & 64.0 & 124.0 & 100.0 \\
\hline Лесная & $\begin{array}{l}\text { Западного Подмосковья } \\
\text { стационары }\end{array}$ & $1951,1952,1964-1966$ & Зябь, н/п & 57.0 & 120.0 & 86.8 \\
\hline Лесная & Истринский стационар & $\begin{array}{c}1938-1940,1950,1951,1953 \\
1955-1978,1991,1994-1996 \\
2000-2006\end{array}$ & Зябь, н/п & 10.2 & 233.0 & 86.4 \\
\hline Лесная & $\begin{array}{l}\text { Подмосковная воднобалан- } \\
\text { совая станция }\end{array}$ & $1956-1986$ & Зябь, н/п & 0.3 & 190.0 & 73.0 \\
\hline Лесная & $\begin{array}{l}\text { Прибалтийская водноба- } \\
\text { лансовая станция }\end{array}$ & 1951-1982, 1984 & Зябь, н/п & 4.0 & 187.3 & 67.4 \\
\hline Лесная & Собакино-агрометстанция & $1925,1926,1928,1929$ & Зябь, н/п & 12.0 & 77.0 & 43.4 \\
\hline Лесная & Тосненская станция & $1935-1940$ & Зябь, н/п & 76.0 & 132.0 & 104.2 \\
\hline $\begin{array}{l}\text { Лесо- } \\
\text { степная }\end{array}$ & $\begin{array}{l}\text { Балашовская сельскохозяй- } \\
\text { ственная опытная станция }\end{array}$ & $1952-1955$ & $\begin{array}{l}\text { Зябь } \\
\text { н/п }\end{array}$ & $\begin{array}{l}0.0 \\
0.8\end{array}$ & $\begin{array}{r}60.0 \\
111.0\end{array}$ & $\begin{array}{l}26.5 \\
45.0\end{array}$ \\
\hline $\begin{array}{l}\text { Лесо- } \\
\text { степная }\end{array}$ & $\begin{array}{l}\text { Богуславская воднобалан- } \\
\text { совая станция }\end{array}$ & $\begin{array}{c}1950-1953,1964,1975-1977 \\
1979,1981\end{array}$ & $\begin{array}{l}\text { Зябь } \\
\text { н/п }\end{array}$ & $\begin{array}{l}0.0 \\
0.0\end{array}$ & $\begin{array}{l}69.3 \\
85.6\end{array}$ & $\begin{array}{l}19.1 \\
31.4\end{array}$ \\
\hline $\begin{array}{l}\text { Лесо- } \\
\text { степная }\end{array}$ & Вязовский стационар & 1964-1966, 1968, 1970 & $\begin{array}{l}\text { Зябь } \\
\text { н/п }\end{array}$ & $\begin{array}{r}0.0 \\
26.0\end{array}$ & $\begin{array}{l}39.0 \\
50.0\end{array}$ & $\begin{array}{l}19.4 \\
36.2\end{array}$ \\
\hline $\begin{array}{l}\text { Лесо- } \\
\text { степная }\end{array}$ & Каменная степь & $\begin{array}{l}1952,1953,1955,1956, \\
1958-1966,1968,1969\end{array}$ & $\begin{array}{l}\text { Зябь } \\
\text { н/п }\end{array}$ & $\begin{array}{l}0.3 \\
0.3\end{array}$ & $\begin{array}{r}84.7 \\
143.0\end{array}$ & $\begin{array}{l}29.9 \\
63.6\end{array}$ \\
\hline $\begin{array}{l}\text { Лесо- } \\
\text { степная }\end{array}$ & Курский стационар ИГ & $\begin{array}{c}\text { 1959-1971, 1973-1974, } \\
1976-1978\end{array}$ & $\begin{array}{l}\text { Зябь } \\
\text { н/п }\end{array}$ & $\begin{array}{l}0.1 \\
3.8\end{array}$ & $\begin{array}{r}98.0 \\
176.0\end{array}$ & $\begin{array}{l}27.2 \\
55.6\end{array}$ \\
\hline $\begin{array}{l}\text { Лесо- } \\
\text { степная. }\end{array}$ & $\begin{array}{l}\text { Нижнедевицкая водноба- } \\
\text { лансовая станция }\end{array}$ & $\begin{array}{c}1953-1955,1958-1970 \\
1972-1974\end{array}$ & $\begin{array}{l}\text { Зябь } \\
\text { н/п }\end{array}$ & $\begin{array}{r}6.0 \\
13.0\end{array}$ & $\begin{array}{l}157.7 \\
192.2\end{array}$ & $\begin{array}{l}58.7 \\
80.1\end{array}$ \\
\hline $\begin{array}{l}\text { Лесо- } \\
\text { степная }\end{array}$ & Новосильская АГЛОС & 1959-1997, 2003-2016 & $\begin{array}{l}\text { Зябь } \\
\text { н/п }\end{array}$ & $\begin{array}{l}0.0 \\
0.0\end{array}$ & $\begin{array}{l}146.0 \\
186.0\end{array}$ & $\begin{array}{l}21.8 \\
29.0\end{array}$ \\
\hline $\begin{array}{l}\text { Лесо- } \\
\text { степная }\end{array}$ & Придеснянская & $\begin{array}{c}1930,1933,1937.1949,1950 \\
1952-1954,1956,1957,1960 \\
1961,1963,1964,1966-1977\end{array}$ & $\begin{array}{l}\text { Зябь } \\
\text { н/п }\end{array}$ & $\begin{array}{l}0.0 \\
0.1\end{array}$ & $\begin{array}{l}195.0 \\
151.9\end{array}$ & $\begin{array}{l}37.4 \\
48.2\end{array}$ \\
\hline $\begin{array}{l}\text { Лесо- } \\
\text { степная }\end{array}$ & $\begin{array}{l}\text { Тимашевский опорный } \\
\text { пункт }\end{array}$ & $1952,1954-1958$ & $\begin{array}{l}\text { Зябь } \\
\text { н/п }\end{array}$ & $\begin{array}{l}0.0 \\
4.7\end{array}$ & $\begin{array}{r}60.0 \\
155.0\end{array}$ & $\begin{array}{l}13.1 \\
64.5\end{array}$ \\
\hline $\begin{array}{l}\text { Степ- } \\
\text { ная }\end{array}$ & $\begin{array}{l}\text { Волгоградское опытное } \\
\text { хозяйство }\end{array}$ & $\begin{array}{c}1950,1957-1981,1983,1984 \\
1986-1998,2000,2003-2005 \\
2009,2010,2015,2016\end{array}$ & $\begin{array}{l}\text { Зябь } \\
\text { н/п }\end{array}$ & $\begin{array}{l}0.0 \\
0.0\end{array}$ & $\begin{array}{l}45.0 \\
76.0\end{array}$ & $\begin{array}{r}3.4 \\
14.8\end{array}$ \\
\hline $\begin{array}{l}\text { Степ- } \\
\text { ная }\end{array}$ & $\begin{array}{l}\text { Дубовская воднобалансовая } \\
\text { станция }\end{array}$ & $\begin{array}{c}1952-1955,1957-1961,1964 \\
1966,1968-1970\end{array}$ & $\begin{array}{l}\text { Зябь } \\
\text { н/п }\end{array}$ & $\begin{array}{l}0.0 \\
0.0\end{array}$ & $\begin{array}{r}56.0 \\
109.0\end{array}$ & $\begin{array}{r}9.8 \\
30.4\end{array}$ \\
\hline
\end{tabular}


Таблица 1. Окончание

\begin{tabular}{|c|c|c|c|c|c|c|}
\hline \multirow[b]{2}{*}{ Зона } & \multirow[b]{2}{*}{ Станция } & \multirow[b]{2}{*}{ Годы наблюдений } & \multirow{2}{*}{$\begin{array}{c}\text { Состояние сельско- } \\
\text { хозяйственных } \\
\text { угодий осенью }\end{array}$} & \multicolumn{3}{|c|}{ Сток, мм } \\
\hline & & & & $\begin{array}{c}\text { мини- } \\
\text { мальный }\end{array}$ & $\begin{array}{c}\text { макси- } \\
\text { мальный }\end{array}$ & $\begin{array}{c}\text { сред- } \\
\text { Ний }\end{array}$ \\
\hline Степ- & Ершовский стационар & $1953-1956$ & Зябь & 0.4 & 54.0 & 21.7 \\
\hline ная & & & $\mathrm{H} / \Pi$ & 20.0 & 118.0 & 74.0 \\
\hline Степ- & Камышинский опорный & $1960-1964,1968,1970$ & Зябь & 0.0 & 21.0 & 5.1 \\
\hline ная & пункт & & $\mathrm{H} / \Pi$ & 1.0 & 88.0 & 38.9 \\
\hline Степ- & Кинельская гидрологиче- & $1952-1957$ & Зябь & 10.0 & 131.0 & 49.0 \\
\hline ная & ская станция & & $\mathrm{H} / \Pi$ & 6.0 & 147.0 & 79.2 \\
\hline Степ- & Поволжская АГЛОС & 1959-1994, 2001-2009, 2011- & Зябь & 0.0 & 54.0 & 7.1 \\
\hline ная & & 2016 & Н/п & 0.0 & 127.0 & 34.5 \\
\hline Степ- & Толстовская гидрологиче- & 1937-1941, 1957 & Зябь & 0.3 & 119.0 & 30.7 \\
\hline ная & ская станция & & н/п & 12.0 & 107.0 & 49.2 \\
\hline Степ- & Энгельская гидрологиче- & $1951-1956$ & Зябь & 0.0 & 16.0 & 6.5 \\
\hline ная & ская станция & & $\mathrm{H} / \Pi$ & 0.2 & 76.0 & 36.9 \\
\hline
\end{tabular}

* Не распахиваемые осенью поля.

на которых проводятся наблюдения за ВПСС и определяющими их факторами, так и условия проведения этих наблюдений (размеры площадок, экспозиция, уклоны, почвенные характеристики, типы севооборотов, характер обработки почвы, виды противоэрозионных мероприятий и др.). Таким образом, при проведении наблюдений во многих случаях практически не соблюдены условия однородности постановки и проведения исследований этого процесса.

Несмотря на это, неоднократно предпринимались попытки использовать хорошо апробированный в гидрологии аппарат теоретических функций распределения вероятности (ФРВ) для аппроксимации эмпирических данных о ВПСС и оценки стока разной повторяемости, обзоры и конкретные примеры которых приведены в [3, 10]. Однако известно, что практически все широко применяемые в гидрологии ФРВ достаточно хорошо аппроксимируют эмпирические данные в области средних значений вероятности превышения (обеспеченности). В то же время в области низких обеспеченностей использование различных теоретических ФРВ дает значительно различающиеся оценки максимальных значений исследуемых характеристик [32, 35]. При этом для оценки статистических параметров этих ФРВ использовались гораздо более длительные ряды наблюдений за речным стоком, чем имеются для ВПСС. Поэтому полученные в литературе оценки максимальных значений ВПСС с использованием теоретических ФРВ для отдельных станций нужно рассматривать только как вероятностные.

Возможно, применение новых методов статистического анализа, таких как метод L-моментов, дающих хорошие результаты для коротких, неоднородных рядов [8, 9], позволит уточнить полученные значения экстремального ВПСС. Но есть и другой подход, использованный нами и основанный на принципе эргодичности - тождественности гидрологических проявлений во времени и в пространстве, разумеется, при максимально близких условиях формирования стока в этом пространстве [20]. В настоящей работе кривые обеспеченности данных стоковых площадок объединены в один ряд отдельно для каждой природной зоны - южной части лесной (подзона смешанных лесов), лесостепной и степной. Кривые построены дифференцированно для двух периодов - до 1980 и после 1980 г. (современный период). Временна́я граница (1980г.) приблизительно определяется произошедшими в это время на территории Русской равнины существенными изменениями климатических условий - потеплением климата, особенно в зимний период. Кроме того, примерно в это же время, а особенно с 1990-х годов, произошло изменение структуры угодий, прежде всего уменьшение площадей под зяблевой (осенней) пахотой под яровые культуры и увеличение площадей, не распахиваемых осенью. А это имеет принципиальное значение, поскольку инфильтрация воды в почву, распахиваемую осенью, значительно превышает инфильтрацию на полях, не распахиваемых с осени (стерня, озимые, залежь, многолетние травы). Соответственно, на зяби ниже поверхностный сток. Особенно это заметно в лесостепной и отчасти в степной зонах, где во многие годы сток на разных угодьях равен нулю. 


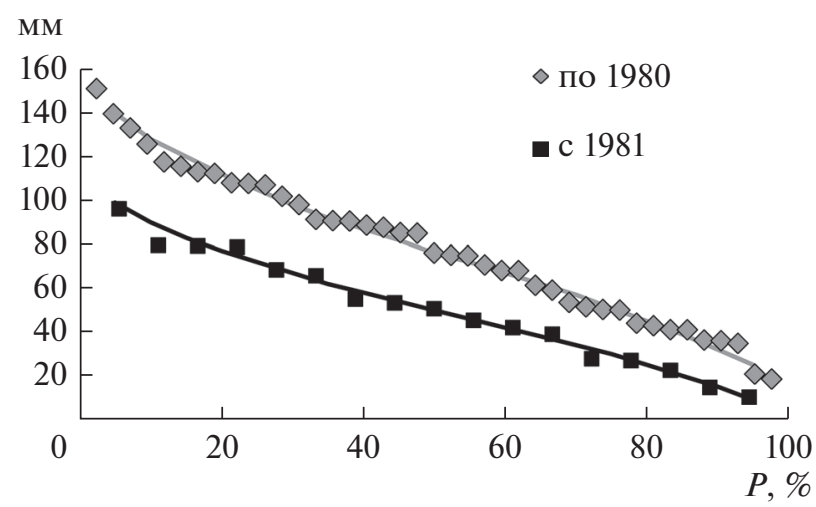

Рис. 1. Кривые обеспеченности средневзвешенного с учетом структуры сельскохозяйственных угодий весеннего поверхностного склонового стока в лесной зоне Русской равнины.

В лесной зоне, в условиях повышенного увлажнения, различия в инфильтрации и поверхностном стоке с угодий с наличием или отсутствием осенней обработки почвы относительно невелики. В отдельные годы сток с зяби в лесной зоне может быть даже выше, чем с полей, не распахиваемых осени. В период до 1980 г. зябь занимала в лесостепной зоне в среднем около $60 \%$, а в степной зоне около $70 \%$ площади сельскохозяйственных угодий на склонах, а после 1980 г. - соответственно 40 и 50\%. Для лесостепной и степной зон кривые обеспеченности значений ВПСС строились отдельно для зяби и полей, не распахиваемых с осени, по данным параллельных наблюдений, а также в целом для склонового стока с учетом соотношения этих угодий. В лесной зоне, где различия в стоке с угодий с наличием или отсутствием осенней обработки почвы относительно невелики, как и число лет параллельных наблюдений на этих угодьях, строились объединенные кривые обеспеченности величин ВПСС на зяби и полях, не распахиваемых осенью, для каждого из двух периодов. Для всех зон использовались данные наблюдений только на суглинистых и глинистых почвах, преобладающих на сельскохозяйственных угодьях на Русской равнине. К объективным проблемам выполненного обобщения относится значительное сокращение числа действующих воднобалансовых станций после 1980 г.

\section{ЗОНАЛЬНЫЕ ВЕЛИЧИНЫ ВЕСЕННЕГО ПОВЕРХНОСТНОГО СКЛОНОВОГО СТОКА В ГОДЫ РАЗЛИЧНОЙ ВОДНОСТИ}

На рис. 1-3 представлены кривые обеспеченности величин стока для отдельных природных зон, а в табл. 2 - сводные значения величин стока $10,25,50,75$ и 90\%-ной обеспеченности.

Как видно из их анализа, практически во все годы ВПСС в лесостепной и степной зонах меньше на зяби, чем на не распахиваемых осенью угодьях. Исключение составляют самые маловодные годы, когда сток на склонах на всех угодьях отсутствует. Этот вывод полностью согласуется с результатами, полученными за более ранний период [3, 22, 29, 39]. Так, до 1981 г. сток в лесостепной зоне на зяби был меньше, чем с не распаханных с осени полей: в многоводные годы $10 \%$-ной обеспеченности в 1.3 раза, в средние по водности годы $50 \%$-ной обеспеченности в 1.6 раза, в маловодные годы 75\%-ной обеспеченности - в 2 раза. В степной зоне в период до 1981 г. сток на зяби был ниже, чем на полях, не распахиваемых с осени, более чем в 3 раза в многоводные годы, в 7 раз в средние по водности годы и в 20 раз - в маловодные годы. В современный период эти различия еще больше, составляя в годы $10 \%$-ной обеспеченности 1.5 раза в лесостепной зоне и более 4 раз в степной зоне. И в лесостепной, и в степной зонах в современный период даже в год $50 \%$-ной обеспеченности
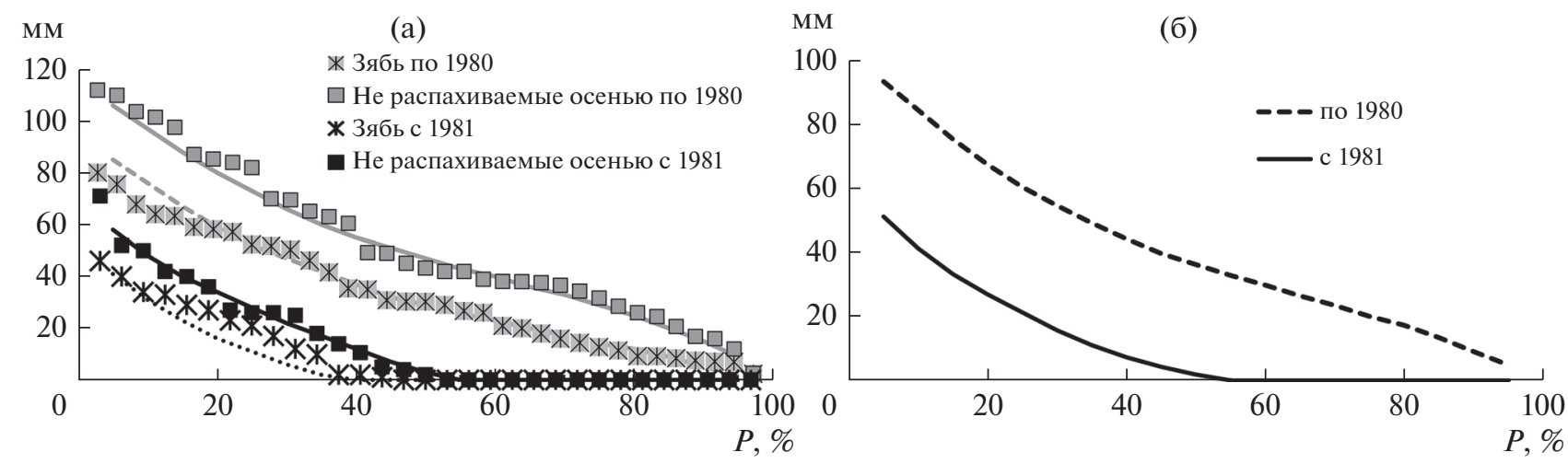

Рис. 2. Кривые обеспеченности весеннего поверхностного склонового стока в лесостепной зоне Русской равнины: (а) эмпирические распределения и их аппроксимации для зяби и полей, не распахиваемых осенью, (б) средневзвешенного стока с учетом структуры сельскохозяйственных угодий. 
MM

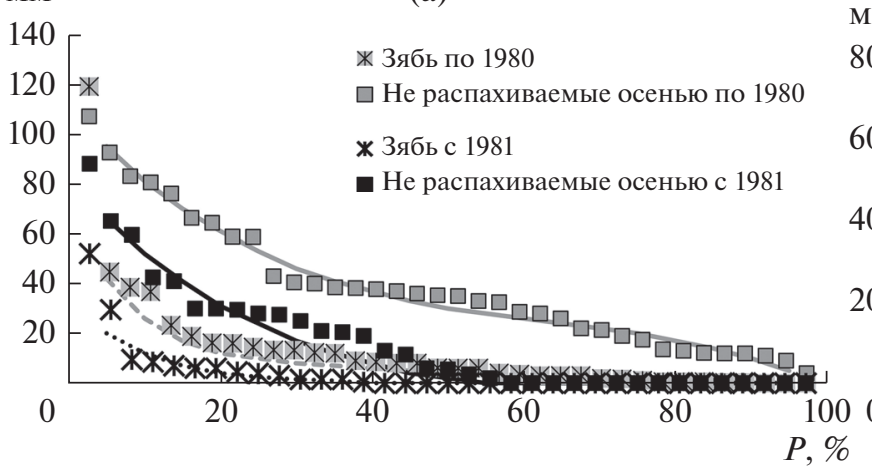

(б)

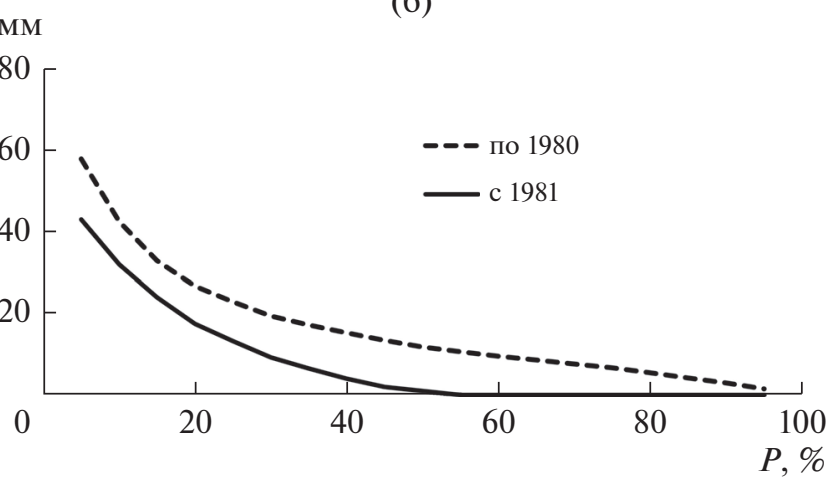

Рис. 3. Кривые обеспеченности весеннего поверхностного склонового стока в степной зоне Русской равнины: (а) эмпирические распределения и их аппроксимации для зяби и полей, не распахиваемых осенью, (б) средневзвешенного стока с учетом структуры сельскохозяйственных угодий.

сток на зяби отсутствует, а в маловодные годы стока нет на всех угодьях. При этом интересно, что наибольший гидрологический эффект зяблевой пахоты в абсолютных значениях (в мм слоя стока) проявляется в многоводные и средние по водности годы. Отметим, что из-за сокращения числа наблюдений на воднобалансовых станциях во второй период мы можем лишь очень ориентировочно судить о ВПСС в многоводные годы $10 \%$-ной и меньшей обеспеченности. Для уверен- ных выводов о характеристиках многоводных лет требуются дополнительные исследования.

Еще один интересный вывод из анализа изученных данных - резкое уменьшение ВПСС в последние десятилетия, обусловленное главным образом изменением климата. Так, в южной части лесной зоны сток в год $10 \%$-ной обеспеченности снизился по сравнению с предшествующим периодом более чем в 1.4 раза, в лесостепной в 2.0 раза, в степной зоне - в 1.3 ра-

Таблица 2. Квантили зонального поверхностного весеннего склонового стока на Русской равнине в $1925-1980$ и 1981-2016 гг., мм

\begin{tabular}{|c|c|c|c|c|c|c|c|}
\hline \multirow{2}{*}{ Зона } & \multicolumn{7}{|c|}{ ВПСС, мм } \\
\hline & лесная & & лесостепная & & & степная & \\
\hline $\begin{array}{l}\text { вероят- } \\
\text { ность, \% }\end{array}$ & $\begin{array}{c}\text { средне- } \\
\text { взвешенный }\end{array}$ & с зяби & $\begin{array}{c}\text { с полей, } \\
\text { не распаханных с осени }\end{array}$ & $\begin{array}{c}\text { средне- } \\
\text { взвешенный }\end{array}$ & с зяби & $\begin{array}{c}\text { с полей, } \\
\text { не распаханных с осени }\end{array}$ & $\begin{array}{c}\text { средне- } \\
\text { взвешенный }\end{array}$ \\
\hline
\end{tabular}

\begin{tabular}{r|r}
10 & 128 \\
25 & 105 \\
50 & 76 \\
75 & 51 \\
90 & 32 \\
10 & 90 \\
25 & 72 \\
50 & 50 \\
75 & 30 \\
90 & 15 \\
\hline
\end{tabular}

\begin{tabular}{c|c|}
76 & \\
52 & \\
29 & \\
14 & \\
5 & $\mid$
\end{tabular}

97

\begin{tabular}{c|}
31 \\
11 \\
0 \\
0 \\
0
\end{tabular}

1925-1980 гг.

73

47

29

15

(5)

60

36

20

9

1981-2016 гг.

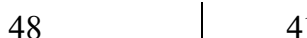

28

3

0

0

\begin{tabular}{r|r}
41 \\
21 \\
2 \\
0 \\
0
\end{tabular}

\begin{tabular}{c|}
26 \\
10 \\
4 \\
1 \\
0
\end{tabular}

81

53

43

23

12

7

3

10

\begin{tabular}{r|}
12 \\
3 \\
0 \\
0 \\
0
\end{tabular}


за. В годы 50\%-ной обеспеченности соответствующее соотношение составляет $1.5,18,12$ раз. В маловодные годы 75\%-ной обеспеченности ВПСС снизился в 1.7 раза в южной части лесной зоны, а в лесостепной и степной зонах в настоящее время он практически отсутствует. Заметим, что если изменения климата способствовали уменьшению стока, то характер хозяйственной деятельности в последние годы способствовал его увеличению за счет того, что сократились площади под зяблевой пахотой, особенно в степной зоне. Снизился объем вносимых в почву минеральных и органических удобрений, улучшающих почвенную структуру, которая в свою очередь влияет на инфильтрационную способность почв. Сократилось проведение разнообразных противоэрозионных мероприятий, способствовавших уменьшению склонового стока. Однако влияние изменения климатических условий оказалось значительно сильнее, что, в конечном итоге, привело к указанному снижению ВПСС.

\section{Последствия изменения ВПСС в современный период}

Произошедшие изменения имеют как положительные, так и негативные последствия. Возросла инфильтрация воды в почву, что способствовало повышению урожайности сельскохозяйственных культур, снижению масштабов разрушительных половодий, которые стали все в большей мере формироваться за счет стока с площади гидрографической сети. Увеличилась доля устойчивого стока подземного происхождения, уменьшилась внутригодовая неравномерность стока. Снизилась интенсивность эрозионных процессов на склонах и выноса загрязняющих веществ в реки и водоемы с ВПСС. Вместе с тем возросли потери воды на пути от склонов к водным объектам, уменьшились ресурсы речного стока, что особенно сказалось в бассейне Дона, как это хорошо показано в работах $[13,18]$. Возросло загрязнение подземных вод.

Вся совокупность последствий произошедших изменений весеннего поверхностного склонового стока на Русской равнине заслуживает специального рассмотрения.

\section{ВЫВОДЫ}

1. Весенний поверхностный склоновый сток одно из наиболее важных гидрологических явлений, в значительной степени определяющее формирование и функционирование наземных и водных геосистем в течение всего года.

2. Выполнено обобщение данных 28 воднобалансовых станций разных организаций и ведомств. На основании их анализа рассчитана величина весеннего поверхностного склонового стока в годы различной водности на территории южной части лесной, в лесостепной и степной зонах Русской равнины. Для лесостепной и степной зон расчет выполнен отдельно для стока с сельскохозяйственных полей под зябью и полей, не распаханных с осени. Для этих зон получены средневзвешенные оценки ВПСС с учетом соотношения площадей, занятых нераспаханными с осени и распаханными полями. Для южной части лесной зоны расчет выполнен объединенно для всех сельскохозяйственных угодий, без разделения их по признаку наличия или отсутствия осенней вспашки. Все оценки получены для двух периодов - до 1981 г. и современного - после 1981 г.

3. Подтверждены ранее полученные разными авторами выводы о существенно меньшем стоке с зяби по сравнению с полями, не распахиваемыми с осени в лесостепной и степной зонах. Исключение - самые маловодные годы, когда весенний поверхностный склоновый сток на всех угодьях отсутствует. В то же время показано, что в абсолютных значениях (в мм слоя) наибольшие различия между этими угодьями наблюдаются в многоводные и средние по водности годы, а наименьшие - в маловодные.

4. Выявлено повсеместное существенное снижение поверхностного склонового стока в современный период (с 1981 г.), что имеет как позитивные, так и негативные последствия. Главный позитивный результат - увеличение запасов почвенной влаги, что способствовало повышению урожайности сельскохозяйственных культур, снижение интенсивности эрозии и выноса загрязняющих веществ в реки и водоемы, а также рост устойчивого речного стока подземного происхождения. Негативный результат - общее снижение ресурсов речного стока, формирующихся главным образом в весенний период на склонах и на площади гидрографической сети, усиление загрязнения подземных вод.

5. Для более полных выводов о динамике весеннего поверхностного стока и последствиях его изменений в современный период и в будущем было бы чрезвычайно важно располагать сведениями большего, чем имеется сегодня, количества воднобалансовых станций. Реанимация работы ранее существовавших станций и открытие новых с программой работ, соответствующей решению назревших актуальных задач гидрологии и водного хозяйства, в частности, изучения путей оптимального регулирования ВПСС - одна из необходимых, по нашему мнению, задач гидрологического и гидроэкологического мониторинга.

\section{ФИНАНСИРОВАНИЕ}

Работа выполнена при поддержке РФФИ (грант 18-05-00479) и в рамках Госзадания 0148-2019-0007. 


\section{FUNDING}

The study was carried out within the framework of the state-ordered research theme of the Institute of Geography RAS, no. 0148-2019-0007, and with financial support received from the RFBR (project no. 18-05-00479).

\section{СПИСОК ЛИТЕРАТУРЫ}

1. Алексеевский Н.И., Коронкевич Н.И., Литвин Л., Чалов Р.С., Ясинский С.В. Сток и эрозия почвы на водосборах как факторы экологической обстановки на реках // Изв. РАН. Сер. геогр. 2000. № 1. С. 52-63.

2. Антропогенное перераспределение органического вещества в биосфере / под. ред. И.С. Коплан-Дикca, Е.А. Стравинской. СПб.: Наука, 1993. 205 с.

3. Барабанов А.T. Агролесомелиорация в почвозащитном земледелии. Волгоград: ВНИАЛМИ, 1993. $155 \mathrm{c}$.

4. Барабанов А.Т., Балычев Р.Д. Оценка поверхностного стока талых вод на Европейской части РФ, его прогноз и мероприятия по регулированию // Современные проблемы земледелия и экологии: сб. докладов. Курск, 2002. С. 122-126.

5. Барабанов А.Т., Долгов С.В., Коронкевич Н.И. Влияние современных изменений климата и сельскохозяйственной деятельности на весенний поверхностный склоновый сток в лесостепных и степных районах Русской равнины // Водные ресурсы. 2018a. T. 45. № 4. C. 332-340.

6. Барабанов А.Т., Долгов С.В., Коронкевич Н.И., Панов В.И., Петелько А.И. Поверхностный сток и инфильтрация в почву талых вод на пашне в лесостепной и степной зонах Восточно-Европейской равнины // Почвоведение. 2018б. № 1. С. 66-72.

7. Бобровицкая Н.Н. Исследование и расчет смыва почвы со склонов // Сб. работ по гидрологии. № 12. Л.: Гидрометеоиздат, 1977. С. 93-99.

8. Болгов М.В., Осипова Н.В. Новые стохастические модели и методы в инженерной гидрологии (обзор) // Современные проблемы стохастической гидрологии. М.: ИВП РАН, 2004. С. 30-36.

9. Болгов М.В., Писаренко В.Ф. О распределении максимальных расходов рек Приморья // Водные ресурсы. 1999. Т. 26. № 6. С. 636-646.

10. Бондаренко Ю.В. Эрозионно-гидрологическое обоснование систем адаптивно-ландшафтных мелиораций водосборов. Саратов: ФГОУ ВПО “Саратовский ГАУ”, 2002. 184 с.

11. Борзилов В.А., Коноплев А.В., Ревина С.К. и др. Экспериментальные исследования смыва радионуклидов, выпавших на почву в результате аварии на Чернобыльской АЭС // Метеорология и гидрология. 1988. № 11. С. 43-53.

12. Вода России. Малые реки / под ред. Черняева А.М. Екатеринбург: АКВА-ПРЕСС, 2001. 804 с.

13. Водные ресурсы России и их использование / под ред. И.А. Шикломанова. СПб.: Государственный гидрологический ин-т, 2008. 600 с.

14. Водогрецкий B.E. Влияние агро- лесо-мелиораций на годовой сток. Методика исследований и расчеты. Л.: Гидрометеоиздат, 1979. 184 с.
15. Герасименко В.П., Кумани М.В. Весенний сток и смыв почв в Центрально-Черноземной зоне // Водные ресурсы. 1980. № 1. С. 185-188.

16. Гинзбург K.E. Фосфор основных типов почв СССР. М.: Наука, 1981. 242 с.

17. Грин А.М. Динамика водного баланса ЦентральноЧерноземного района. М.: Наука, 1965. 148 с.

18. Джкамалов Р.Г., Киреева М.Б., Косолапов А.Е., Фролова Н.Л. Водные ресурсы бассейна Дона и их экологическое состояние. М.: ГЕОС, 2017. 205 с.

19. Здоровцев И.П., Дощечкина Г.В. Актуальные вопросы рационального регулирования эрозионно-гидрологических процессов в агроландшафтах Среднерусской возвышенности // 18-е пленарное межвузовское координационное совещание по проблеме эрозионных, русловых и устьевых процессов. Курск, 2003. С. 123-124.

20. Калинин Г.П. Проблемы глобальной гидрологии. Л.: Гидрометеоиздат, 1968. 377 с.

21. Коплан-Дикс И.С., Назаров Г.В., Кузнецов В.К. Роль минеральных удобрений в эвтрофировании вод суши. Л.: Наука, 1985. 184 с.

22. Коронкевич Н.И. Водный баланс Русской равнины и его антропогенные изменения. М.: Наука, 1990. 204 c.

23. Коронкевич Н.И. Снегозапасы и поверхностный сток по данным воднобалансовых станций // Географо-гидрологические исследования. М., 1992. C. $41-76$.

24. Коронкевич Н.И. Экстремальная водность года: ее проявления и последствия // Изв. РАН. Сер. геогр. 2002. № 1. С. 20-27.

25. Коронкевич Н.И., Чернышов Е.П. Воздействие на водные ресурсы и эрозию на начальной стадии их формирования // Природные ресурсы Русской равнины в прошлом, настоящем и будущем. М.: Наука, 1976. С. 295-320.

26. Коронкевич Н.И., Ясинский С.В. О современном состоянии изучения поверхностного стока в основных почвенных зонах Европейской России // Почвоведение. 1999. № 9. С. 1001-1009.

27. Кузнецов М.С., Демидов В.В. Эрозия почв лесостепной зоны Центральной России: моделирование, предупреждение и экологические последствия. М.: Полтекс, 2002. 183 с.

28. Литвин Л.Ф. География эрозии почв сельскохозяйственных земель России. М.: ИКЦ “Академкнига", 2002. 255 с.

29. Львович М.И. Человек и воды: Преобразование водного баланса и речного стока. М.: Географгиз, $1963.568 \mathrm{c}$.

30. Назаров Г.В. Гидрологическая роль почвы. Л.: Наука, 1981. $216 \mathrm{c.}$

31. Петров Б.Г. Географические аспекты организации водоохранных мероприятий на крупных равнинных водохранилищах (на примере Куйбышевского). Автореф. дис. ... канд. геогр. наук. Ярославль, 2004. 24 c.

32. Рождественский А.В., Чеботарев А.И. Статистические методы в гидрологии. Л.: Гидрометеоиздат, 1974. 422 c. 
33. Субботин А.И. Сток талых и дождевых вод. М.: Гидрометеоиздат, 1966. 375 с.

34. Тушинский С.Г., Шинкар Г.Г. Загрязнение и охрана природных вод. Охрана природы и воспроизводство природных ресурсов / Итоги науки и техники. Т. 12. М.: ВИНИТИ АН СССР, 1982. 109 с.

35. Христофоров А.В. Надежность расчетов речного стока. М: Изд-во Моск. ун-та, 1993. 165 с.

36. Чернышов Е.П., Иванова Н.Б. Потери органических и минеральных веществ почвами центра и юга Рус- ской равнины при снеготаянии // Почвоведение. 1993. № 2. С. 73-83.

37. Эрозия почвы / пер. с англ. М.: Колос, 1984. 415 с.

38. Ясинский С.В., Гусев Е.М. Динамико-стохастическое моделирование процессов формирования весеннего склонового стока на малых водосборах // Почвоведение. 2003. № 7. С. 761-774.

39. Ясинский С.В., Кашутина Е.А. Пространственные и временные закономерности изменения весеннего склонового и речного стока на Русской равнине // Изв. РАН. Сер. геогр. 2007. № 5. С. 71-81.

\title{
Spring Slope Runoff on the Russian Plain in Years of Different Water Content
}

\author{
E. A. Kashutina ${ }^{1}$, S. V. Yasinskii ${ }^{1}$, and N. I. Koronkevich ${ }^{1, \#}$ \\ ${ }^{1}$ Institute of Geography RAS, Moscow, Russia \\ \#e-mail: hydro-igras@yandex.ru \\ Received May 13, 2019; revised July 2, 2019; accepted October 3, 2019
}

\begin{abstract}
The important hydrological and hydro-ecological role of slope runoff, especially in spring (SSR), is shown. The data of 28 water balance stations on the SSR value on the territory of the Russian Plain in the years of different water flow are summarized. The hydrological role of autumn ploughing in the forest-steppe and steppe zones is shown. It leads to SSR decrease on the fields of autumn ploughing in comparison with the SSR on the fields not plowed in autumn, and most significantly in high-water and average years. The exception is the driest years, when there is no surface slope runoff on all lands. Two periods are considered - from the 1920 s to 1980 and from 1981 to the present time. They are characterized by different climate features and anthropogenic impact. It is revealed that the SSR in the second period has reduced dramatically (by several times), mainly as a result of climate change, which has both positive and negative consequences.
\end{abstract}

Keywords: spring snowmelt, spring slope runoff, autumn ploughing, fields not plowed since autumn, periods before 1980 and after 1980, changes, consequences

\section{REFERENCES}

1. Alekseevskii N.I., Koronkevich N.I, Litvin L. Chalov R.S., Yasinskii S.V. Runoff and soil erosion in catchments as environmental factors in rivers. $I z v$. Akad. Nauk, Ser. Geogr., 2000, no. 1, pp. 52-63. (In Russ.).

2. Antropogennoe pereraspredelenie organicheskogo veshchestva $v$ biosphere [Anthropogenic Redistribution of Organic Matter in the Biosphere]. Koplan-Diks I.S., Stravinskaya E.A., Eds. St. Petersburg: Nauka Publ., 1993. 205 p.

3. Barabanov A.T. Agrolesomelioratsiya v pochvozashchitnom zemledelii [Agroforestry in Soil Protection Agriculture]. Volgograd: VNIALMI Publ., 1993. 155 p.

4. Barabanov A.T., Balychev R.D. Assessment of melt water surface runoff in the European part of the Russian Federation, its forecast and regulatory measures. In Sovremennye problemy zemledeliya i ekologii [Modern Problems of Agriculture and Ecology]. Kursk, 2002, pp. 122-126. (In Russ.).

5. Barabanov A.T., Dolgov S.V., Koronkevich N.I. Effect of present-day climate changes and agricultural activities on spring overland runoff in forest-steppe and steppe regions of the Russian plain. Water Resour., 2018, vol. 45 , no. 4 , pp. 447-454.

doi 10.1134/S009780781804005X
6. Barabanov A.T., Dolgov S.V., Koronkevich N.I., Panov V.I., Petel'ko A.I. Surface runoff and snowmelt infiltration into the soil on plowlands in the forest-steppe and steppe zones of the East European plain. Eurasian Soil Sci., 2018, vol. 51, no. 1, pp. 66-72. doi 10.1134/S1064229318010039

7. Bobrovitskaya N.N. Research and calculation of the soil loss from the slopes. In Sb. rabot po gidrologii [Collection of Hydrological Works]. Leningrad: Gidrometeoizdat, 1977, vol. 12, pp. 93-99. (In Russ.).

8. Bolgov M.V., Osipova N.V. New stochastic models and methods in engineering hydrology (review). In Sovremennye problemy stokhasticheskoi gidrologii [Modern Problems of Stochastic Hydrology]. Moscow: Inst. Vodn, Probl., RAN, 2004, pp. 30-36. (In Russ.).

9. Bolgov M.V., Pisarenko V.F. The distribution of peak runoff values of the Primorye rivers. Vodn. Resur., 1999, vol. 26, no. 6, pp. 636-646. (In Russ.).

10. Bondarenko Yu.V. Erozionno-gidrologicheskoe obosnovanie sistem adaptivno - landshaftnykh melioratsii vodosborov [Erosion and Hydrological Study of the Systems of Adaptive - Landscape Reclamation Watershed]. Saratov: FGOU VPO Saratovskii GAU, 2002. $184 \mathrm{p}$.

11. Borzilov V.A., Konoplev A.V., Revina S.K., et al. Experimental studies of radionuclides flushing that fell on the ground as a result of the Chernobyl accident. Mete- 
orologiya i Gidrologiya, 1988, no. 11, pp. 43-53. (In Russ.).

12. Voda Rossii. Malye reki [Water of Russia. Small Rivers]. Chernyaev A.M., Ed. Ekaterinburg: AKVA-PRESS Publ., 2001. 804 p.

13. Vodnye resursy Rossii i ikh ispol'zovanie [Water Resources of Russia and Their Use]. Shiklomanov I.A., Ed. St. Petersburg: Gos. Gidrol. Inst., 2008. 600 p.

14. Vodogretskii V.E. Vliyanie agro- leso-melioratsii na godovoi stok. Metodika issledovanii i raschety [Impact of Agroforestry on Annual Runoff. Research Methods and Calculations]. Leningrad: Gidrometeoizdat Publ., 1979. $184 \mathrm{p}$.

15. Gerasimenko V.P., Kumani M.V. Spring runoff and soil flushing in the Central-Chernozem Area. Vodn. Resur., 1980, no. 1, pp. 185-188. (In Russ.).

16. Ginzburg K.E. Fosfor osnovnykh tipov pochv SSSR [Phosphorus of the Main Types of Soils of the USSR]. Moscow: Nauka Publ., 1981. 242 p.

17. Grin A.M. Dinamika vodnogo balansa Tsentral'noChernozemnogo raiona [Dynamics of Water Balance of the Central Chernozem Area]. Moscow: Nauka Publ., 1965. $148 \mathrm{p}$.

18. Dzhamalov R.G., Kireeva M.B., Kosolapov A.E., Frolova N.L. Vodnye resursy basseina Dona i ikh ekologicheskoe sostoyanie [Water Resources of the Don Basin and Their Ecological State]. Moscow: GEOS Publ., 2017. 205 p.

19. Zdorovtsev I.P., Doshchechkina G.V. Topical issues of rational regulation of erosion-hydrological processes in agricultural landscapes of the Central Russian upland. In 18-e plenarnoe mezhvuzovskoe koordinatsionnoe soveshchanie po probleme erozionnykh, ruslovykh $i$ ust'evykh protsessov [18th Plenary Interuniversity Coordination Meeting on Erosion, Channel and Estuarine Processes]. Kursk, 2003, pp. 123-124. (In Russ.).

20. Kalinin G.P. Problemy global'noi gidrologii [Problems of Global Hydrology]. Leningrad: Gidrometeoizdat Publ., 1968. 377 p.

21. Koplan-Diks I.S., Nazarov G.V., Kuznetsov V.K. Rol' mineral'nykh udobrenii $v$ evtrofirovanii vod sushi [The Role of Mineral Fertilizers in Eutrophication of Land Waters]. Leningrad: Nauka Publ., 1985. 184 p.

22. Koronkevich N.I. Vodnyi balans Russkoi ravniny $i$ ego antropogennye izmeneniya [Water Balance of the Russian Plain and its Anthropogenic Changes]. Moscow: Nauka Publ., 1990. 204 p.

23. Koronkevich N.I. Snow reserves and runoff according water balance stations. Geogr.-Gidrologicheskie Issled., Moscow, 1992, pp. 41-76. (In Russ.).

24. Koronkevich N.I. Extreme water content of the year: its reflection and consequences. Izv. Akad. Nauk, Ser. Geogr., 2002, no. 1, pp. 20-27. (In Russ.).

25. Koronkevich N.I., Chernyshov E.P. Impact on water resources and erosion at the initial stage of their formation. In Prirodnye resursy Russkoi ravniny $v$ proshlom, nastoyashchem $i$ budushchem [Natural Resources of the
Russian Plain in the Past, Present and Future]. Moscow: Nauka Publ., 1976, pp. 295-320. (In Russ.).

26. Koronkevich N.I., Yasinskii S.V. On the present situation in the investigation of surface runoff in the main soil zones of the European part of Russia. Pochvovedenie, 1999, vol. 32, no. 9, pp. 1001-1009. (In Russ.).

27. Kuznetsov M.S., Demidov V.V. Eroziya pochv lesostepnoi zony Tsentral'noi Rossii: modelirovanie, preduprezhdenie i ekologicheskie posledstviya [Soil Erosion in the Forest-steppe Zone of Central Russia: Modelling, Prevention and Environmental Consequences]. Moscow: Polteks Publ., 2002. 183 p.

28. Litvin L.F. Geografiya erozii pochv sel'skokhozyaistvennykh zemel' Rossii [Geography of Soil Erosion of Agricultural Lands of Russia]. Moscow: Akademkniga Publ., 2002. 255 p.

29. L'vovich M.I. Chelovek $i$ vody: Preobrazovanie vodnogo balansa i rechnogo stoka [Man and Water: Transformation of Water Balance and River Flow]. Moscow: Geografgiz Publ., 1963. 568 p.

30. Nazarov G.V. Gidrologicheskaya rol' pochvy [Hydrological Role of Soil]. Leningrad: Nauka Publ., 1981. 216 p.

31. Petrov B.G. Geographical aspects of the organization of water protection measures in large flat reservoirs (on the example of Kuibyshev one). Extended Abstract of Cand. Sci. (Geogr.) Dissertation. Yaroslavl': Inst. Ecol. Natur. Systems, Tatarstan Akad. Sci., 2004. 24 p.

32. Rozhdestvenskii A.V., Chebotarev A.I. Statisticheskie metody v gidrologii [Statistical Methods in Hydrology]. Leningrad: Gidrometeoizdat Publ., 1974. 422 p.

33. Subbotin A.I. Stok talykh i dozhdevykh vod [Melt and Rainwater Runoff]. Moscow: Gidrometeoizdat Publ., 1966. 375 p.

34. Tushinskii S.G., Shinkar G.G. Zagryaznenie i okhrana prirodnykh vod. Okhrana prirody $i$ vosproizvodstvo prirodnykh resursov [Pollution and Protection of Natural Waters. Protection of Nature and Reproduction of Natural Resources]. Moscow: VINITI AN SSSR, 1982. 109 p. (In Russ.).

35. Khristoforov A.V. Nadezhnost' raschetov rechnogo stoka [Reliability of River Flow Calculations]. Moscow: Mosk. Gos. Univ., 1993. 165 p.

36. Chernyshov E.P., Ivanova N.B. Loss of organic and mineral substances by soils of the Center and South of the Russian plain during snowmelt. Pochvovedenie, 1993, no. 2, pp. 73-83. (In Russ.).

37. Eroziya pochvy [Soil Erosion]. Moscow: Kolos Publ., 1984. $415 \mathrm{p}$.

38. Yasinskii S.V., Gusev E.M. Dynamic-stochastic modeling of spring slope runoff in small drainage areas. Pochvovedenie, 2003, vol. 36, no. 7, pp. 761-774. (In Russ.).

39. Yasinskii S.V., Kashutina E.A. Spatial and temporal patterns of changes in spring slope runoff and river flow on the Russian plain. Izv. Akad. Nauk, Ser. Geogr., 2007, no. 5, pp. 71-81. (In Russ.). 